358. 距骨下関節不安定症における荷重撮影法の試み

\title{
A trial of load ragiography on instability in the subtalar joint
}

\author{
大阪医科大学放射線科 \\ ○濱田 松治西端豊井八崎 光彦 \\ (Matsuji Hamada) (Yutaka Nisibata) (Mitsuhiko Inosaki) \\ 竹内 正保楢林 勇 \\ (Masayasu Takeuti)． (Isamu Narabayasi)
}

【目 的】

距骨下関節不安定症の検査法には、様々な方法があるが簡便な方法で関節 に十分なストレスを加えることができ、客観的に不安定症を評価する方法は 確立されておらず、主観的な判断に頼っているのが現状である。そこで、距 骨下関節にストレスを加えた場合の足部矢状面での距骨と踵骨の関係を観察 するために、後距踵関節を描出させるアントンセン撮影法を応用し、片脚立 位荷重撮影を試みたところ定量的評価の可能性を見いだしたので報告する。

【方 法】

本学で開発した立位専用撮影台にスポンジを張り付けた硬質発泡スチロー ルを置き、その上に患者を立たせる。検側の足部外側にカセッテをおき、足 底基準線をカセッテ面より踵部を $40^{\circ}$ 管球側に向ける。荷重撮影は、非検側 の足を前方に出し片脚立位とする。非荷重撮影は、非検側の足を後方に引き 検側の足底がスポンジを軽く触れる程度にする。この際、足底面と下腿軸は 垂直にする。中心X線は頭尾方向に $20^{\circ}$ 傾け内果に向けて斜入する。(Fig. 1) 荷重時のX線写真を( Fig. 2 )に示す。

評価方法は、距骨下関節における踵骨に対する距骨の移動距離を距骨前方 移動距離（a）とし、距骨前方移動距離と後距踵関節踵骨関節面の長径 (b) との比を距骨前方移動率とする。（Fig. 3） 足部に疾患のない健常成人 40 人 80 関節、男性 28 人、女性 12 名を対象とした。

\section{【結 果】}

1. 非荷重と荷重時の距骨前方移動距離, 率は、統計学的に有意な差であった

2. 距骨前方移動距離および移動率は、非荷重、荷重ともに性差、左右差は 認められなかった。

3. 荷重時の状態で距骨下関節の矢状面を明瞭に描出する事が可能になった 【考 察】

1. 荷重時における距骨下関節の距骨前方移動距離を足部矢状面で測定する ことが可能であり、距骨下関節不安定症の定量的評価が可能と思われた

2.徒手によるストレス方法に比べ容易に距骨下関節にストレスを加えるこ とが可能である。

3.最適な足部体位角度と入射角度の検討が必要である。

4 . 臨床例の検討も必要である。

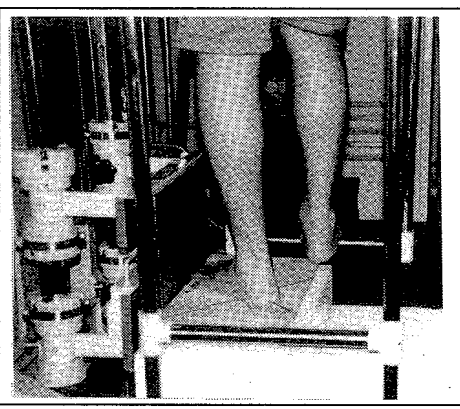

F i g. 1

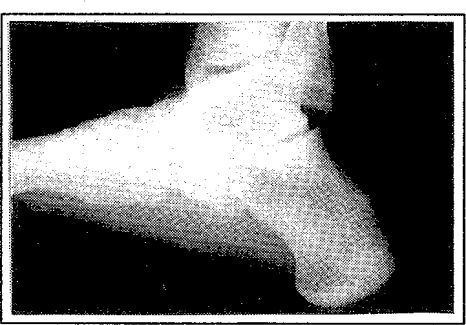

F i g. 2

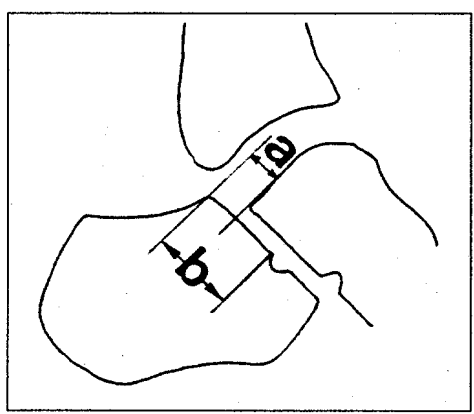

F i g. 3

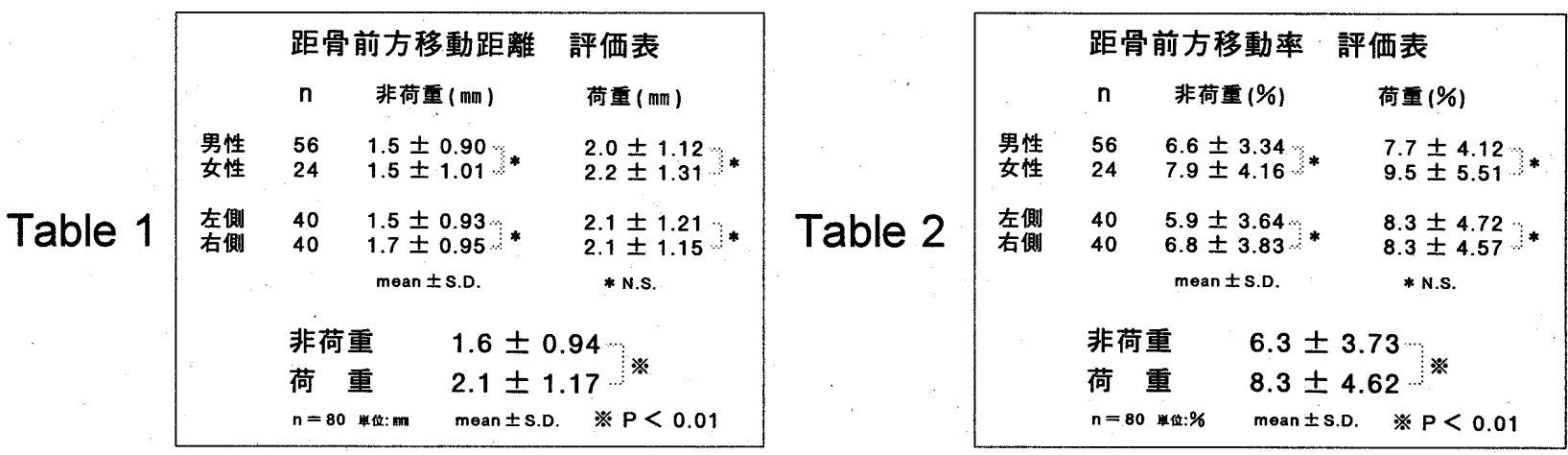

